\title{
STUDIES ON THE USE OF VEGETABLE BASED POLYESTERS AS DIELECTRIC INSULATING FLUIDS IN ELECTRIC EQUIPMENTS
}

Hashem, A. I. ${ }^{(1)}$; El-Deek, M. A. K. ${ }^{(1)}$; El- Debeiky, S. M. ${ }^{(2)}$

Tahoun, F. I. $^{(3)}$ and Abd El-Gawad, Naglaa, A. ${ }^{(3)}$

1) Faculty of Science, Ain Shams University. 2) Faculty of Engineering, Ain Shams University 3) Egyptian Electricity Holding Company.

\begin{abstract}
In this investigation, four vegetable oils namely: linseed, rapeseed, radish and used frying oil were subjected to chemical transesterification to be used as dielectric fluids. thus, transesterification of these natural esters using pentaerythritol led to the formation of the corresponding polyesters.

Each polyester produced was divided into 2 parts: the first part was tested as dielectric fluid according to (American Society for Testing and Materials ASTM) methods and the results were compared with International Standard Specifications (International Electrotechnical Commission IEC). The second part was treated with DBPC (2,6-di-tertbutyl-p-cresol) as an antioxidant additive and then tested as dielectric fluid according to ASTM methods and the results were compared with IEC specifications again.

Linseed polyester and used frying oil polyester gave better results.
\end{abstract}

Keyword: Four vegetable oils, transesterification, dielectric fluid, antioxidant additive

\section{INTRODUCTION}

In the last decades there was an increasing concern in finding substitutes for petroleum refinery products. This is due to the expected depletion of petroleum reservoirs all over the world in the future. Moreover, petroleum 
products and their wastes, being non-biodegradable represent an environmental problem due to the toxicity of most of their components.

Vegetable oils being renewable sources and biodegradable represent suitable candidates for this purpose.(Kodali, 2002; Zhang et al., 2003; Yunus, et al., 2003; Kulkarni et al., 2007) Although vegetable oils suffer from the disadvantage of being susceptible to oxidation due to the presence of allylic hydrogens in their backbone, this problem could be overcome by the use of suitable doses of antioxidant additives. The basic purpose of transformer oil is insulation and cooling. Liquids of non-polar and stable chemicals are suitable. Furthermore, there are other important characteristics such as resistance to temperature, discharge, flashover and breakdown, as well as, good compatibility with the other materials in the transformer. Resistance to oxidation and chemical reaction with cellulose in the presence of moisture and temperatures up to $100^{\circ} \mathrm{C}$ is a particularly essential feature of an enduring insulation system. So the comparison between insulating fluids is not just the testing of the oil itself, but also an investigation of an oil-board system. The different moisture behavior of the insulation liquids must also be considered for its interaction with the impregnated cellulose. Mineral oil can only absorb water in amounts of some 10's of ppm (at room temperature), natural and synthetic esters can bind water many times over that ( Pukel et al., 2009)

Natural Esters in place of mineral oils have many advantages. The insulation system needs to be designed with the dielectric properties of the materials in mind. The permittivity of natural ester fluid is higher than the permittivity of mineral oil. This will affect the permittivity of the Kraft 
insulation, which is impregnated with the respective fluid. The electrical stress in a solid/liquid insulation system will distribute inversely proportional to the permittivity. Because the permittivity of natural ester fluid is closer to that of impregnated Kraft than mineral oil there will be more stress in the solid insulation in the case of natural ester fluid. This needs to be analyzed by the insulation system designer with the use of Finite Element Modeling. However, it should be an advantage where the stress in the fluid limits the average stress (Prevost, 2006).

Special factors have to be considered concerning the design and impregnation of sealed power transformers. Particularly in combination with vacuum type tap-changers, certain limitations apply to ensure operational safety (Tenbohlen et al., 2008). Oxidation stability of vegetable oils depends on fatty acids distribution and the presence of natural antioxidants. The higher the degree of unsaturation in the oil the lower its oxidation stability.

Oxidation stability of vegetable oils also depends on the refining process of the oil. The refining process consists of several steps that reduce the concentration of free fatty acids, waxes, metals, coloring pigments and odors but also contribute to the reduction of the concentration of natural antioxidants as tocopherols (Diestre et al., 2011).

Some natural ester dielectric fluids are produced and used in market they have better dielectric properties than mineral oils. They have dielectric constants closer to that of paper thus lowering the dielectric stress level at the paper/ liquid interface. For these reasons, the dielectric designs used are directly suitable for use with natural ester dielectric fluids(Moore, 2006). 
In addition to the many positive aspects like the higher biodegradability, high flash point and good properties concerning the AC electrical strength, esters have also negative features, which should be taken into account in the design phase and during the exploitation of the transformer with esters. The parameters of the designed transformer must be based on the knowledge about these negative features. Designer should know that the esters are susceptible to the action of a concentrated heat flux, have the worse cooling properties than mineral oils, and lower lightning strength.

In this investigation, we wish to report on the possibility of using some vegetable oils, after chemical modification as substitutes of transformer oils of petroleum origin.

Four selected oils were transesterified with pentaerythritol producing natural polyester which are tested according to ASTM and the results are compared with IEC standard specifications. The produced natural polyesters were treated with DBPC (2,6-di-tert-butyl-p-cresol) antioxidant additive to show the effect of antioxidant on them after comparing results with IEC standards.

\section{EXPERIMENTAL}

1-Materials: Linseed oil, Rapeseed oil, Radish oil, Used sunflower oil. The four vegetable oils were filtered to reduce impurities before reaction.

2-Chemicals: Pentaerythritol, xylene, p-toluenesulphonic acid and DBPC (2,6-ditert-butyl-p-cresol). These chemicals were obtained from SigmaAldrich chemicals company and Algmhoria chemicals company 


\section{2-1-Conversion of vegetable oils into methyl esters}

$10 \mathrm{~g}$ Of solid sodium hydroxide(1\%wt. of oil) dissolved in $200 \mathrm{ml}$ methanol were mixed with $1000 \mathrm{~g}$ oil in conical flask with a magnetic stirrer. the reactants were heated at $50-55^{\circ} \mathrm{C}$ with stirring 300 r.p.m for $3 \mathrm{hrs}$. The contents of the flask were then transferred to a separating funnel, whereby the methyl ester was obtained as the upper layer with $70 \%$ yield. The ester obtained was then dried to get rid of moisture.

\section{2-2-Conversion of the methyl ester into polyester}

The methyl ester (4mol.) was mixed with pentaerythritol (1mol.) ptoluenesulphonic acid $(1 \mathrm{~g})$ and xylene $(20 \mathrm{ml}$.). The reaction mixture was heated under nitrogen atmosphere at $150-180^{\circ} \mathrm{C}$ for $6 \mathrm{hrs}$. The reaction mixture was washed thoroughly with methanol to dissolve any unreacted methyl ester. Finally, the product was heated at $70^{\circ} \mathrm{C}$ to evaporate any methanol present. (Hashem, et al., 2010).

\section{2-3-Tests performed on the polyesters obtained Breakdown voltage( ASTM D1816)}

Breakdown voltage is the voltage when spark appears between two electrodes immerged in the oil, separated by specific gap $(2.5 \mathrm{~mm})$. Slowly rising voltage was applied between the electrodes. The rate of rising voltage was generally controlled at $2 \mathrm{kv} / \mathrm{s}$ and the voltage at which sparking started between the electrodes was observed. Generally this measurement was performed 3 to 6 times to the same sample of oil and the average values of these reading were taken. The breakdown voltage was measured using the ASTM D1816. 


\section{Flash point (IP34\&35)}

Flash point is the temperature at which the vapors above an oil sample start to ignite giving a momentary flash when exposed to flame under specified conditions of test

The measuring of flash point depends on heating the oil sample gradually at and a small flame is directed into its surface at constant rate until vapor ignition occurs.

Flash point is important because it specifies the chances of fire hazard in the transformer.

\section{Pour point (ASTM D-97)}

It is the minimum temperature at which oil is observed to flow when cooled and examined under prescribed conditions. Pour Point of transformer oil is an important property mainly at the places where climate is extremely cold. If the oil temperature falls below the pour point, transformer oil stops convection flowing and obstruct cooling in transformer.

\section{Kinematic Viscosity (ASTM D445)}

Good oil should have low viscosity so that it offers less resistance to the convectional flow of oil thereby not affecting the cooling of transformer.

The time was measured in seconds for fixed volume of liquid to flow under gravity through the capillary of a calibrated viscometer under a reproducible driving head and at a closely controlled temperature $40^{\circ} \mathrm{C}$ and $100^{\circ} \mathrm{C}$ 


\section{Water content (ASTM D6304)}

Moisture or water content in transformer oil is highly undesirable as it affects adversely the dielectric properties of oil. The water content in oil also affects the paper insulation of the core and winding of transformer. Paper is highly hygroscopic in nature. It absorbs maximum amount of water from oil which affects paper insulation property and reduce its life. Water content is measured using coulometric Karl Fisher titration.

\section{Acidity (ASTM D-974)}

Total acid number is the quantity of base, expressed in milligrams of potassium hydroxide required to neutralize all acidic constituent present in one gram of sample. Acidity of transformer oil is harmful property, it deteriorates the insulation property of paper insulation of winding and accelerates the oxidation process of the oil.

\section{Oxidation stability(ASTM D2272)}

This test method utilizes an oxygen-pressured vessel to evaluate the oxidation stability of oil in the presence of water and a copper catalyst coil at $150^{\circ} \mathrm{C}$.

The test oil, water, and copper catalyst coil, contained in a covered glass container, were placed in a vessel equipped with a pressure gage. The vessel was charged with oxygen to a gage pressure of $620 \mathrm{kPa}$ (90 psi, $6.2 \mathrm{bar}$ ) placed in a constant-temperature oil bath set at $150^{\circ} \mathrm{C}$, and rotated axially at $100 \mathrm{rpm}$ at an angel of $30^{\circ}$ from the horizontal axis. The number of minutes required to reach a specific drop in gage pressure is the oxidation stability of the test sample 


\section{RESULTS AND DISCUSSION}

Studies are continued day by day to achieve a suitable alternative insulating liquid instead of mineral oil because of its high price, being nonbiodegradable and nonrenewable. In this work we converted some inedible vegetable oils into natural polyesters by transesterification reactions with pentaerythritol.

Four vegetable oils namely: linseed, rapeseed, radish seed and used edible oil were subjected to two successive transesterification processes. In the first process, the oils were converted into methyl esters, which were retransesterified with pentaerythritol.

The polyesters obtained were tested as transformer insulating liquids applying the international ASTM standard methods and the results are compared with IEC twice; first time without using antioxidant and the second time with adding DBPC antioxidant to indicate the improvement in their physico-chemical properties.

The results obtained which are listed in Tables1,2 and illustrated by figures18 can be summarized as:

1- Acidity of the polyester obtained from linseed oil is in the border limits of IEC standard and that obtained from used sunflower oil exceeds the limits slightly and this can be treated, easily. But those obtained from rapeseed and radish seed are higher than the upper limit of IEC standards

2- Viscosities of the four polyester samples obtained both at $400 \mathrm{C}$ and at 1000C are in IEC standard limits

3- Pour points of the four samples are in IEC standard limits 
4- The flash points of the four polyesters are better than those of the values of mineral oils, but are still less than the IEC standard values for natural esters although there is an improvement after adding DBPC(2,6-di-tertbutyl-p-cresol) antioxidant.

5- Breakdown voltage is the main function of the insulating liquid and the better the insulating liquid, the higher breakdown voltage it has.

6- Both the polyesters of linseed and frying oil exceeds the lower limits sufficiently and area reliable as insulating liquids. The addition of DBPC (2, 6-di-tert-butyl-p-cresol) antioxidant improved the breakdown voltage clearly.

7- Water contents are in normal limits according to IEC standards for natural esters.

8- Oxidation stability of the polyesters of linseed and frying oil after adding the antioxidant are almost the same and are better than the rest two samples

\section{CONCLUSION}

The results obtained from this study reveal the following:

1. The erythrityl esters of linseed and used frying oil have good insulating properties and can be used safely in power equipments. But, that of used frying oil needs neutralization to remove the slight excess acidity.

2. Being obtained from oil waste, used frying oil has the advantage of being priceless, abundant and compatible with the environmental aspects. 
J. Environ. Sci.

Institute of Environmental Studies and Research - Ain Shams University

\section{Tables}

Table (1): Tests performed on natural polyesters without the antioxidant

\begin{tabular}{|c|c|c|c|c|c||}
\hline Tests & $\begin{array}{c}\text { Linseed } \\
\text { erythrityl }\end{array}$ & $\begin{array}{c}\text { Rapeseed } \\
\text { erythrityl }\end{array}$ & $\begin{array}{c}\text { Radish } \\
\text { erythrityl }\end{array}$ & $\begin{array}{c}\text { used } \\
\text { sunflower oil } \\
\text { erythrityl }\end{array}$ & IEC \\
\hline $\begin{array}{c}\text { Breakdown } \\
\text { voltage }\end{array}$ & 40 & 28 & 25 & 37 & $\geq 35 \mathrm{Kv}$ \\
\hline Flash point & 145 & 131 & 136 & 134 & $\geq 250 \circ \mathrm{C}$ \\
\hline Pour point & -15 & -10 & -13 & -10 & $\leq-10^{\circ} \mathrm{C}$ \\
\hline $\begin{array}{c}\text { Viscosity at } \\
\text { 40॰C }\end{array}$ & 28 & 30 & 25 & 23 & $\leq 50 \mathrm{~mm}^{2} \mathrm{~s}^{-1}$ \\
\hline $\begin{array}{c}\text { Viscosity at } \\
\text { 100 }\end{array}$ & 8 & 6 & 8 & 7 & $\leq 15 \mathrm{~mm}^{2} \mathrm{~s}^{-1}$ \\
\hline $\begin{array}{c}\text { Water } \\
\text { content }\end{array}$ & 47 & 62 & 55 & 70 & $\leq 200 \mathrm{mg}^{-1}$ \\
\hline Acidity & 0.06 & 0.15 & 0.07 & 0.09 & $\leq 0.06 \mathrm{mgKOH}^{-1}$ \\
\hline
\end{tabular}

Table (2): Tests performed on natural polyesters treated with antioxidant

\begin{tabular}{|c|c|c|c|c|c|}
\hline Tests & $\begin{array}{l}\text { Linseed } \\
\text { erythrityl }\end{array}$ & $\begin{array}{l}\text { Rapeseed } \\
\text { erythrityl }\end{array}$ & $\begin{array}{c}\text { Radish } \\
\text { erythrityl }\end{array}$ & $\begin{array}{c}\text { used } \\
\text { sunflower } \\
\text { oil } \\
\text { erythrityl } \\
\end{array}$ & IEC \\
\hline $\begin{array}{c}\text { Breakdown } \\
\text { voltage }\end{array}$ & 45 & 32 & 28 & 38 & $\geq 35 \mathrm{Kv}$ \\
\hline Flash point & 177 & 155 & 140 & 183 & $\geq 250^{\circ} \mathrm{C}$ \\
\hline Pour point & -15 & -10 & -13 & -10 & $\leq-10^{\circ} \mathrm{C}$ \\
\hline $\begin{array}{c}\text { Viscosity at } \\
40^{\circ} \mathrm{C}\end{array}$ & 28 & 30 & 25 & 23 & $\leq 50 \mathrm{~mm}^{2} \mathrm{~s}^{-1}$ \\
\hline $\begin{array}{c}\text { Viscosity at } \\
100^{\circ} \mathrm{C}\end{array}$ & 8 & 6 & 8 & 7 & $\leq 15 \mathrm{~mm}^{2} \mathrm{~s}^{-1}$ \\
\hline Water content & 47 & 62 & 55 & 70 & $\begin{array}{c}\leq 200 \mathrm{mg} \\
\mathrm{kg}^{-1}\end{array}$ \\
\hline Acidity & 0.06 & 0.15 & 0.07 & 0.09 & $\begin{array}{c}\leq 0.06 \mathrm{mg} \\
\mathrm{KOH}\end{array}$ \\
\hline $\begin{array}{c}\text { Oxidation } \\
\text { Stability } \\
\end{array}$ & 44 & 29 & 23 & 43 & \\
\hline
\end{tabular}




\section{Figures}

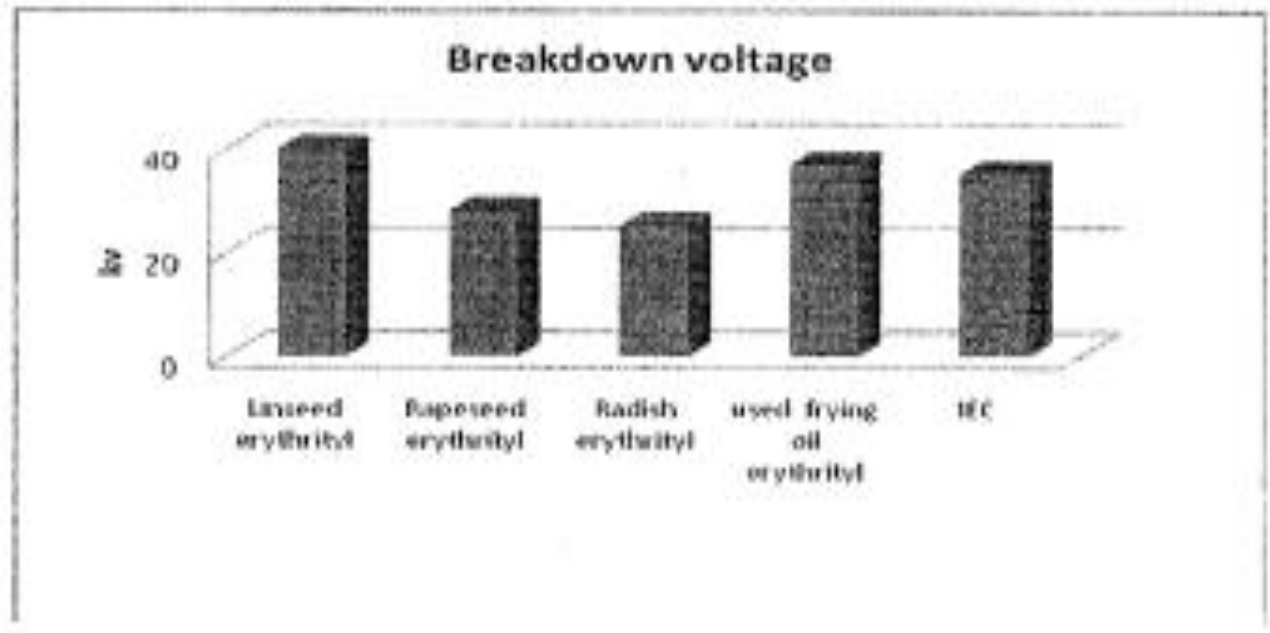

Fie(1)-Breakdow voltages of natural polyesters withoet usiag antiaxidant additive

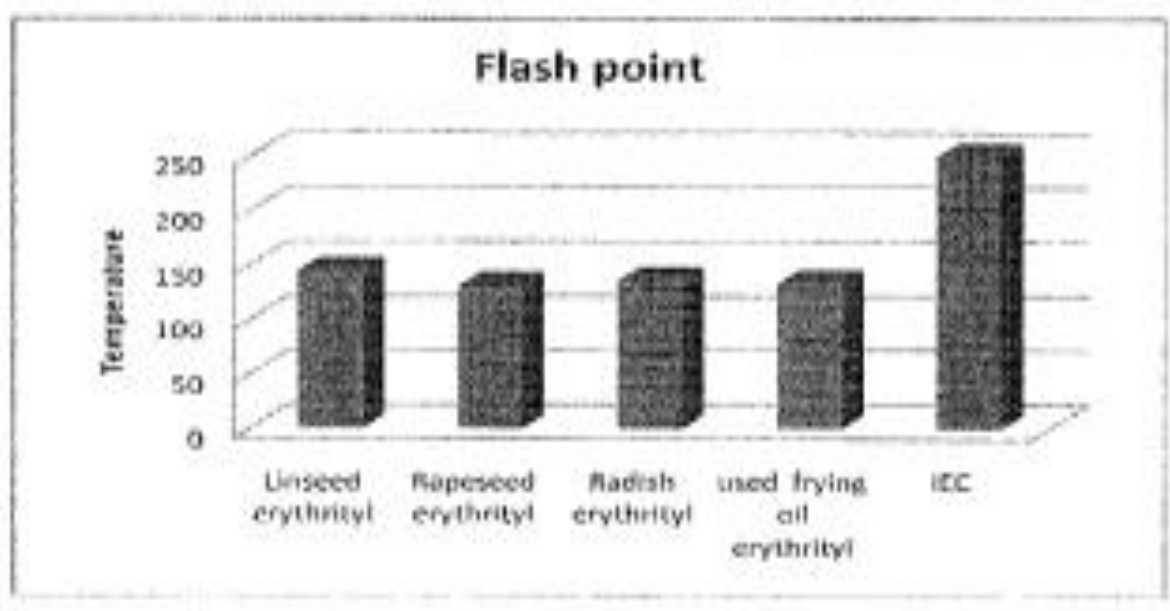

Fiz (a)-Fash points of natural polyesters without using antioxident additive 
J. Environ. Sci.

Institute of Environmental Studies and Research - Ain Shams University

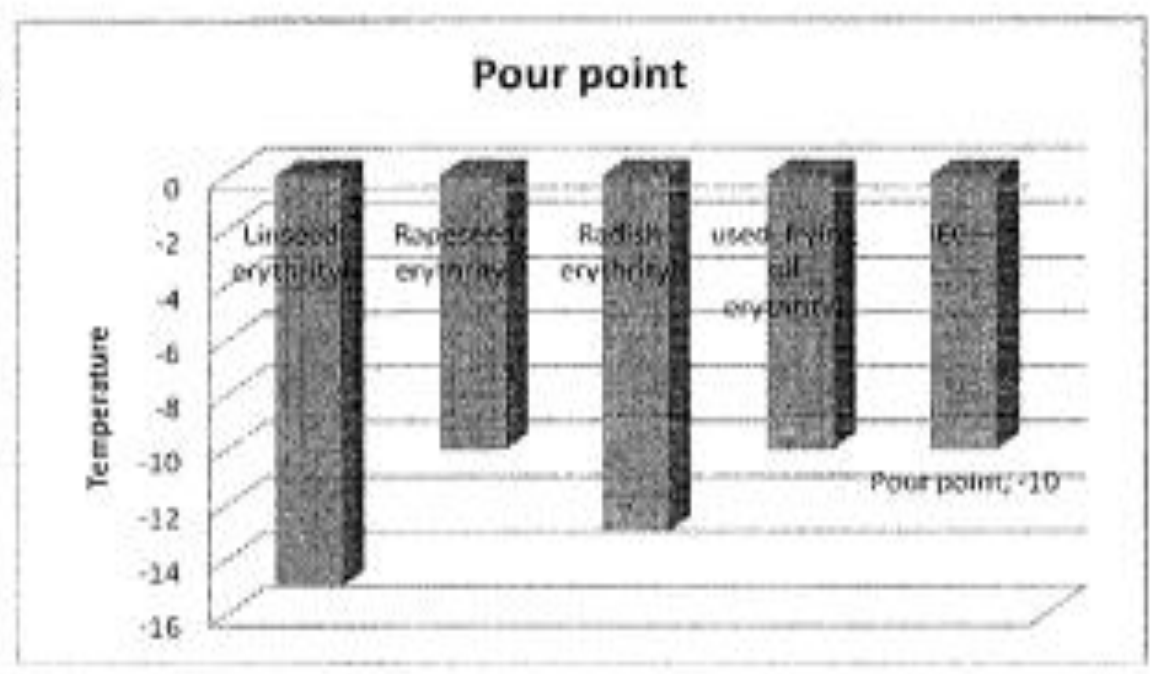

Fig. (3)-pour points of natural polyesters

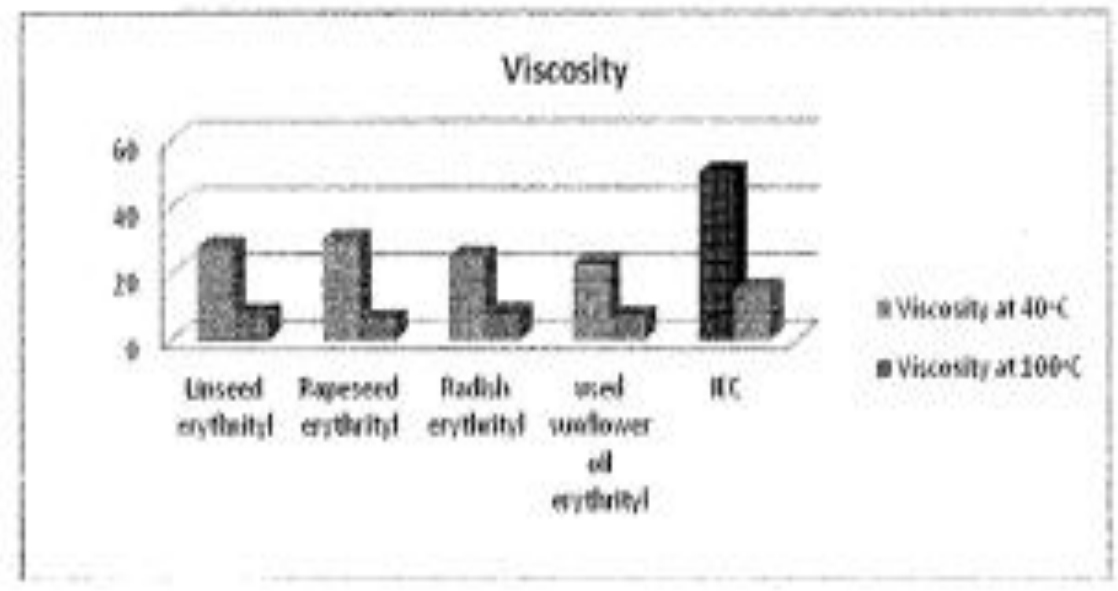

Fig, (4)-Viscosity of natural polyesters 


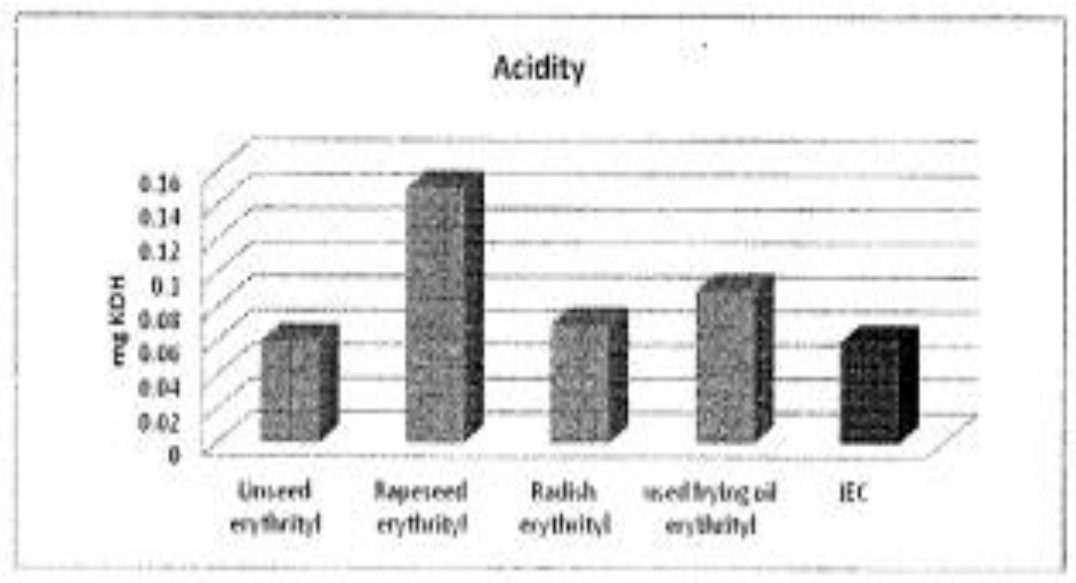

Fig. (5) Acidity of natural polyester

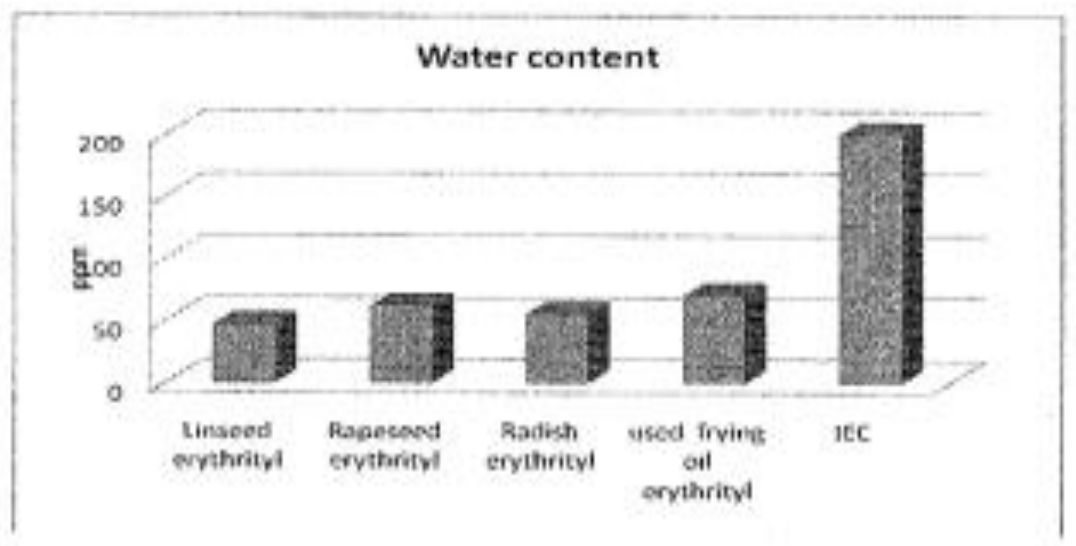

Fig. (6) Water content of natural polyesters 


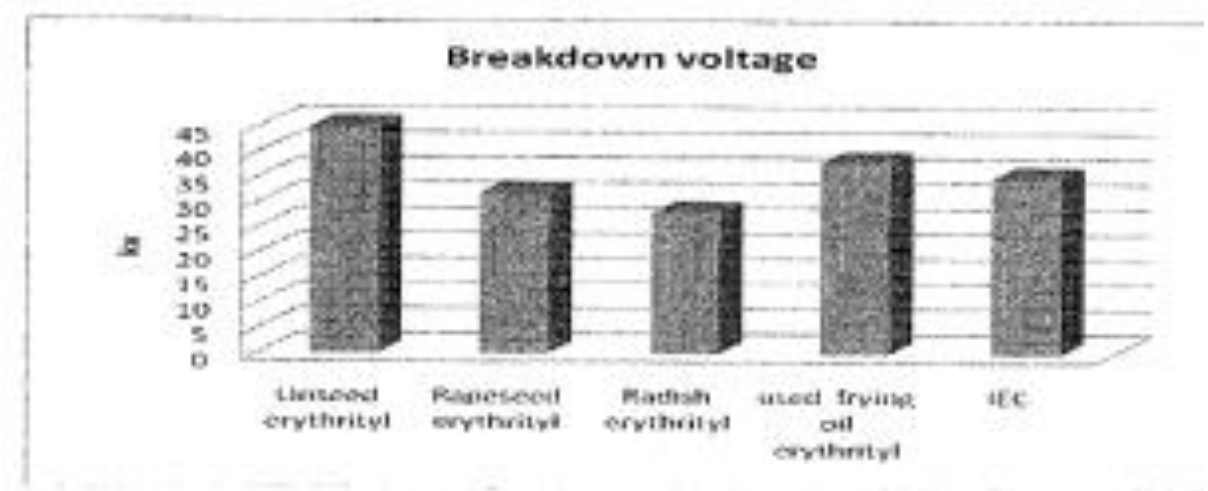

Fig. (7)-Breakdown voltages of natural polyesters using $2 \% \mathrm{w} / \mathrm{w}$ antioxidant additive

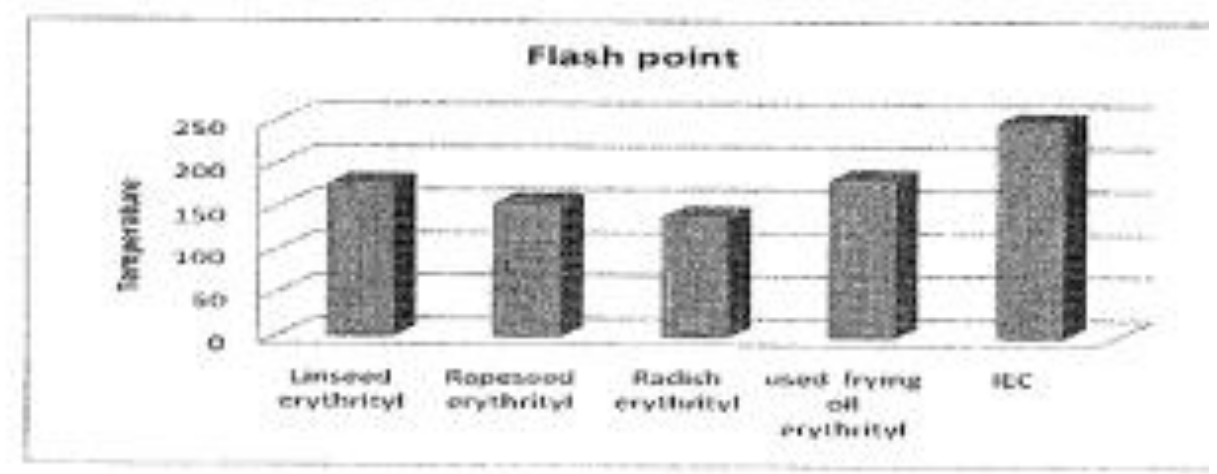

Fig. (8)-Flash points of natural polyester using $2 \% \mathrm{w} / \mathrm{w}$ antioxidant additive

\section{REFERENCES}

Abdel Hamed, A.M (2010): "Preparation and evaluation of some base oils synthesized from vegetable oils" Ph.D. Chemistry DepartmentFaculty of Science- Ain Shams University. 
Diestre, E., Izcara, J. and Sanz, F. (2011): "Oxidation stability of non inhibited vegetable transformer liquids" $21^{\text {st }}$ International Conference on Electricity Distribution, Frankfurt, 6-9 June 2011, paper 0039

Kodali, D. R. (2002): "High performance ester lubricants from natural oils" Indust. J. Lub. \& Tribol. 54: 165-170.

Kulkarni,M. G., Dalai, A. K. and Bakhshi, N. N. (2007): "Transesterification of canola oil in mixed methanol/ethanol system and use of esters as lubricity additive" Biores. Technol.98, 2027-2033.

Moore, S.P. (2006): "Some considerations for new and retrofil applications of natural ester dielectric fluids in medium and large power transformer" IEEE Power Eng. Soc. Transmission and Distribution Conf., pp. 25-29.

Provest, T. A.(2006): "Dielectric properties of natural esters and their influence on transformer insulation system design and performance" Transmission and Distribution Conference and Exhibition, 2005/2006 IEEE PES p. 30-34.

Pukel, G. J., Eberhardt, R.. Muhr, H.M., Baumann, F. and Lick, W. (2009): "Large power transformers for alternative insulating fluids" Proceeding of the 16th international symposium on High Voltage Engineering 2009 SAIEE Johannesburg paper F-27.

Tenbohlen, S., Koch, M., Vukovic, D., Weinläder, A., Baum, J. Harthun, J., Schäfer, M., Frotscher, R., Dohnal, D. and Dyer, P. (2008): "Application of vegetable oil- based insulating fluids to hermetically sealed power transformers) Cigre 2008 A2-102

Yunus, R., Fakhrul-Razi, A., Ooi, T. L., Iyuke, S. E. and Idris, A. (2003): "Development of optimum synthesis method for transesterification of palm oil methyl esters and trimethylol propane to environmentally acceptable palm oil based lubricants" J. Palm Oil Res. 15, 35-41.

Zhang,Z., Dube, M. A., Mclean, D.D., and Kates, M. (2003): "Biodiesel production from waste cooking oil: process design and technological assessment" Biores. Technol. $\underline{89}$, 1-16. 


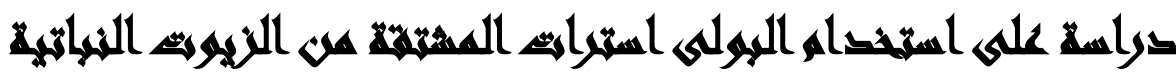

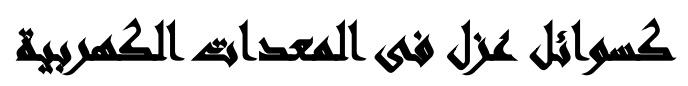

[ч]

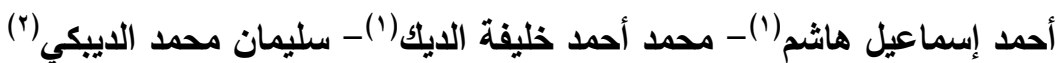

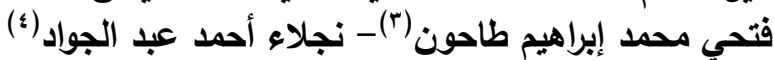

( ) كلية العلوم، جامعة عين شمس ب) كلية الهندسة، جامعة عين شمس بم) الشركة القابضة لكهرباء

\section{المستخلصى}

هناك اهتمام منزايد فى الآونة الأخيرة بدراسة امكانية استخدام الزيوت النباتية بعد اجراء تحوبرات كيميائية عليها كبدائل للزيوت المعدنية لما تتميز به هذه الزبوت الطئية الطبيعية من صفات تجعلها آمنة بيئياً

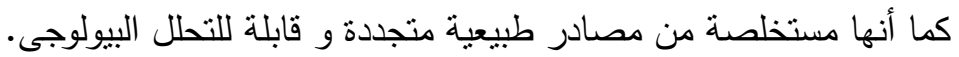

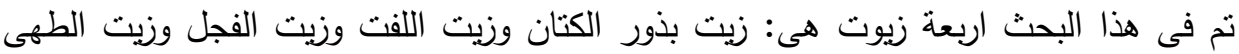

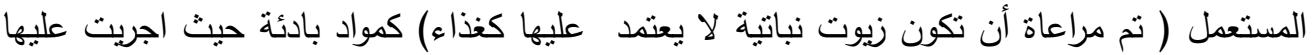
عمليات أسترة تبادلية لتحويلها الى استرات الميثيل كمرحلة أولى، ثم أجريت عليها عملية أسترة تبادلية

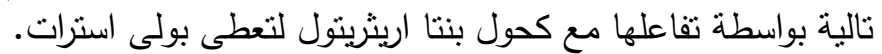
ثم قسمت البولى استرات الى جزئين: الجزء الأول اجريت عليه الاختبارات القياسية العالمية لتحديد خواصه الفيزيقوكيميائية

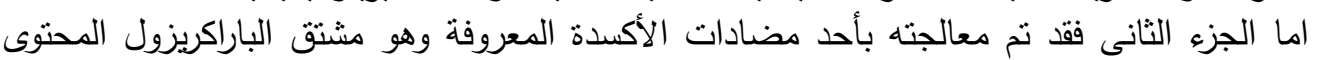

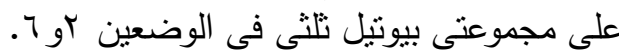
وقد أوضحت النتائج تفوق بولى استرات المشتقة من زيت بذور الكتان وزيت الطهى المستعمل بعد اضافة مضادات الأكسدة بما بتفق والمواصفات القياسية العالمية الكهروتقنية. 